\title{
IAMJ
}

INTERNATIONAL

AYURVEDIC

MEDICAL JOURNAL

\section{PREVENTION OF ALCOHOL ADDICTION THROUGH AYURVEDA - A REVIEW ARTICLE}

\author{
Vishnupriya. $\mathbf{M}^{1}$, Anita Sharma ${ }^{2}$, Sasmita Tripathy ${ }^{3}$ \\ ${ }^{1}$ P.G Scholar (Dept of Swasthavritta and Yoga), \\ ${ }^{2}$ Professor (Dept of Swasthavritta and Yoga), \\ ${ }^{3}$ Lecturer (Dept of Swasthavritta and Yoga) \\ N.P.A. Govt. Ayurved College Raipur, C.G., India
}

Corresponding Author: lachup693@gmail.com

\section{https://doi.org/ $10.46607 /$ iamj2308112020}

(Published online: November 2020)

Open Access

(C) International Ayurvedic Medical Journal, India 2020

Article Received: 23/10/2020 - Peer Reviewed: 08/11/2020 - Accepted for Publication: 11/11/2020

\section{(D) Check for updates}

\section{ABSTRACT}

Addiction is the repeated involvement with a substance or activity, despite the substantial harm it now causes, because that involvement was pleasurable and or valuable. Alcohol is commonly abused due to easy access and the lack of stigma around binge drinking. According to WHO, globally 3.3 million deaths every year result from harmful use of alcohol. Over the past 30-40 years, increasing percentages of young people have started to drink alcoholic beverages, their alcohol consumption has increased in quantity and frequency and the age at which drinking starts has declined. Alcoholism is considered as a disease and alcohol a disease agent, which causes intoxication, cirrhosis, gastritis, pancreatitis etc. It is also an important aetiologic factor in suicide, accidents and injuries. Beyond health consequences, the harmful use of alcohol brings significant social and economic losses to individuals, society at large. Alcoholism prevention is a proactive approach to avoid the adverse effects of alcohol abuse. Prevention should be directed towards developing a healthier lifestyles and mental stability. Ayurveda laid its basement over prevention and maintaining health through right-diet, lifestyles and thinking. It gives emphasis for both body and mind and explained Aahara, Sadvritta, Achara Rasayana, Yoga etc through which one can attain stability of both 
body and mind. From an early stage of life, if one follows these, can master their minds, guide his life and never be a victim of any kind of Addiction.

Keywords: Ayurveda, Addiction, Aahara, Sadvritta, Achara Rasayana

\section{INTRODUCTION}

A compulsive, chronic, physiological or psychological need for a habit-forming substance, behaviour, or activity having harmful physical, psychological or social effects and typically causing well defined symptoms upon withdrawal or abstinence-definition of Addiction according to Merriam Webster Dictionary. Alcoholism is world-wide social and medical problem. In 2016, the harmful use of alcohol resulted in some 3 million deaths worldwide. Of all deaths attributable to alcohol consumption worldwide, $28.7 \%$ were due to injuries, $21.3 \%$ due to digestive diseases, $19 \%$ due to cardiovascular diseases, $12.9 \%$ due to infectious diseases and $12.6 \%$ due to Cancer. ${ }^{1}$ In India, the recorded per capita consumption of pure Alcohol in 2016 was 3.0 litres. While alcohol is used traditionally by men, its use by women is now on the increase. The proportion of dependent users is large. Chronic alcoholism is defined as the regular imbibing of an amount of ethyl alcohol (Ethanol) that is sufficient to harm an individual socially, psychologically or physically. A daily consumption of $40 \mathrm{gm}$ of ethanol (4 small pegs or 2 larger pegs) is likely to be harmful but intake of 100 gm or more daily is certainly is dangerous.

Aetiology

Availability of alcohol and social patterns of use appear be the most important factors. Genetic factors may play some part in predisposition to dependence.

\section{Consequences of Chronic Alcohol Misuse}

\section{Acute Intoxication -}

- Emotional and Behavioural disturbance

- Medical problems: Hypoglycaemia, Aspiration of vomit, Respiratory depression.

- Accidents and injuries.

\section{By harmful use}

\section{Medical consequences}

Neurological - Dementia, Cerebral haemorrhage, Peripheral neuropathy etc, Hepatic - Fatty change and Cirrhosis, Liver Cancer , Gastrointestinal - Gastritis,
Pancreatitis, Oesophageal Cancer etc, Respiratory Pulmonary TB, Pneumonia, Skin - Palmar erythema, Dupuytren's contractures, Cardiac - Cardiomyopathy, Hypertension, Musculoskeletal - Myopathy, fractures, Reproductive - Hypogonadism, Infertility, Psychological problems - Depression, Anxiety, Alcohol Hallucinosis $^{2}$

\section{Treatment}

There are two main elements to intervention in a person with Alcoholism. Motivational interviewing and brief intervention, During Motivational interviewing, the clinicians help the patient to think through the assets and liabilities of the current pattern of drinking. If the patient agrees to stop drinking, sudden decrease in alcohol intake can produce withdrawal symptoms. Once the patient begins to consider change, the emphasis shift to brief interventions designed to help the patient understand more about potential action. Features include tremor of the hands, agitation and anxiety, Autonomic nervous system overactivity including an increase in pulse, respiratory rate and body temperature and insominia. $^{3}$

In Ayurveda, there is explanation of Madya, its Guna and about Madatyaya.

A substance, because of its Tamo guna masks the Buddhi and causes Mada is called Madya. ${ }^{4}$ Madya is hot in potency, penetrating, subtle, nonslimy, dry, quick acting, quick spreading and loosening joints. By its hot potency it wards off cold, by penetrating property it destroys functions of the mind, by minuteness it spreads to all organs, by nonslimy nature it destroys Kapha and Sukra, by dryness it aggravates Vata, by the property of quick acting it does action quickly, by the property of spreading to all parts it bestows pleasure and by the property of loosening it spreads to all parts of the body. ${ }^{5}$

If a person who is Durbala (Weak) and of Tamasika Prakarti consumes excessive Alcohol, all Tridosa get 
vitiated and get localized in the Buddhi. This produce obstructions in the activities of speech, body and mind leading to Vaisamya of Sanjnyavaha and Pranavaha srotases. ${ }^{6}$

After drinking Alcohol four stages of intoxication are observed, First Stage - Pleasant and Decent, Refreshing stage of Alcoholism

Middle Stage - Confusion, excessive talk, excessive movements, incoherence in standing etc

Third Stage - Person become motionless like a cut wood, his mind being covered with narcosis and confusion, though living he appears as dead. ${ }^{7}$ Based on Dosa predominance, it is classified into 4 - Vataja, Pittaja, Kaphaja and Tridosa. Acharyas mentioned treatment according to Dosa predominance. All types of alcoholism are Tridosaja, hence the physician should first treat the Dosa which is predominant therein. In alcoholism the treatment should be started of Kapha because it is predominantly situated flanked by pitta and Vata. This disorder which is caused by faulty, excessive or deficient drinking is pacified by wine itself in proper quantity. ${ }^{8}$

\section{DISCUSSION}

Alcohol withdrawal syndrome is the serious complications facing during intervention Features include tremor of the hands, agitation and anxiety, Autonomic nervous system overactivity including an increase in pulse, respiratory rate and body temperature and insominia. About 2-5\% alcoholics experience a withdrawal seizure, with the risk increasing in the context of concomitant medical problems, misuse of additional drugs, and higher. ${ }^{9}$ So prevention is the best solution for Alcoholism.

People become addicted to alcohol because they are trying to escape from their problems and tensions. The intoxication effect fools them to believe that they are helped from their situations but actually creating imbalances both mentally and physically. The aim of Ayurveda is to fix all the imbalances and provide the individual with the ability to deal better with stress. It has emphasized on foods and activities to be followed for maintaining a healthy body and mind. These are:

\section{Ahara}

Food has given the prime importance since Vedic period. It is considered as Brahma in Upanishad. Kasyapa gives it the name Mahabhaisajya. This is responsible for growth, development and enhancement of Ojas. According to Sri Bhagavat Gita, consumption of food I e. Satvika Ahara makes the mind clear, when mind is devoid of blemishes memory power enhances. ${ }^{10}$

\section{Sadvrtta}

Sadvrtta comprises of two words Sat meaning good and Vrtta meaning Acara or regimen. These are some rules regarding hygiene, speech, diet, urges, study, social relations etc by following this leads to prevention of psychological, physical and psychomatic disorders. ${ }^{11}$

\section{Yoga}

Yoga is the Sanskrit term meaning to join/unite together, that is to bring together body, mind and spirit into a harmonious whole. ${ }^{12}$ The central methods are Asanas (bodily postures), Pranayama (breathing techniques) etc. Aside from the physical benefits, one of the best benefits of yoga is how it helps a person manage stress. The regular practice of yoga postures can improve health and help people with better with stress.

\section{Achara Rasayana}

Acharya Charaka introduced the unique concept of Acharya Rasayana, It is a right code of socio-behavioural conduct, it teach us a preferred life style with defined do's and don'ts, such as worship to Gods, to elders, speaking truth, avoiding excessive indulgence in alcohol, sex and excessive labor, practicing mantra, japa, kind and well behaved, keeping self-peaceful, regular use of milk, ghee and other nutritious elements of diet etc. ${ }^{13}$

Acharyas explained that, the person predominant in Sattva quality enjoys all the merits of Madya without hampering the observance of virtue and wealth. ${ }^{14}$ For improving the Satva Guna, one can follow Satvika diet, as it is explained that what we eat what we become. Also, some codes and conducts through one can control his sense organs. He, who is self-controlled, should withdraw himself from drinking further before he gets disorder of vision and de-arrangement of mind. By adopting measures mentioned in Acharya Rasayana, a person can be free from the emotional disturbances and 
stressful life and maintains both physical and mental stability. Regular Yoga practice creates mental clarity and calmness, increase body awareness, relieves chronic stress pattern, relaxes the mind, centres attention and sharpens concentration.

\section{CONCLUSION}

Madhya by nature is just like food. It is like nectar for that who drinks according to prescribed methods, in proper quantity, in proper time, with wholesome food, according to strength on the contrary, act as poison. Those persons whose mind has been strengthened by following proper diet and regimens and codes of conduct will not become an addict, as self-awareness are important because they can help with early detection of problems and allow for early preventive action.

\section{REFERENCES}

1. Park's Textbook of Preventive and Social Medicine, by K.Park, M/s Banarsidas Bhanot Publishers, Twenty Fifth Edition, 2019, Chapter 19 pg no -896.

2. Davidson's Principles and Practice of Medicine, by Nicki. R. Colledge et al, Churchill Livingstone Elsevier, $21^{\text {st }}$ Edition, 2010, Chapter 10, pg no- 247

3. Harrison's Principles of Internal Medicine, Edited by Dan L Longo et al, Vol II McGraw-Hill companies, $18^{\text {th }}$ Edition 2012, Chapter 33 pg no - 3550

4. 4.The Principles And Practice of Kaya Cikitsa, by Dr. S. Suresh Babu, Chaukhambha Orientalia, Varanasi, Reprint Edition 2013, chapter 49, pg no - 365

5. Susruta Samhita, English Translation Vol. III, Prof. K.R. Srikantha Murthy, Chaukhambha Orientalia Varanasi, Edition 2, 2005, Uttar tantra 47/03 pg no - 305

6. The Principles And Practice of Kaya Cikitsa, by Dr. S. Suresh Babu, Chaukhambha Orientalia, Varanasi, Reprint Edition 2013, chapter 49, pg no - 366

7. Caraka Samhita Caraka-Samhita English Translation, Prof. P.V. Sharma, Vol. II Chaukhambha Orientalia Varanasi, Edition 72005 Chikitsa Sthana 24/41-51, pg no $-394$

8. Caraka Samhita Caraka-Samhita English Translation, Prof. P.V. Sharma, Vol. II , Chaukhambha Orientalia Varanasi, Edition 72005 Chikitsa Sthana 24/107-109, pg no -399
9. Harrison's Principles of Internal Medicine, Edited by Dan L Longo, et al, Vol II, McGraw-Hill companies, $18^{\text {th }}$ Edition 2012, Chapter 33, pg no -3551

10. ATextBook of Svasthavrtta by Dr. Manglagowri V. Rao, Chaukhambha Orientalia, Varanasi, Reprint Edition 2012, Chapter8, pg no -78, 79

11. 11A TextBook of Svasthavrtta by Dr. Manglagowri V. Rao, Chaukhambha Orientalia, Varanasi, Reprint Edition 2012, Chapter4, pg no -51.

12. 12.Swathavrtta Sudha by Dr. Kashinath Samgandi, Ayurved Samskrta Hindi Pusthak Bhandar, Jaipur, Reprint Edition 2017, Chapter -19, pg no - 189

13. 13.Article-Role of Achara Rasayana in Chittovega, by Dr. G. Babu, Research officer, I.G.M.S, Complex, Labbipet, Ancient Science of Life, Vol: No. X X VI

14. Caraka Samhita Caraka-Samhita English Translation, Prof. P.V. Sharma, Vol. II Chaukhambha Orientalia Varanasi, Edition 72005 Chikitsa Sthana 24/107-109, pg no -399

\section{Source of Support: Nil \\ Conflict of Interest: None Declared}

How to cite this URL: Vishnupriya. $M$ et al: Prevention Of Alcohol Addiction Through Ayurveda - A Review Article. International Ayurvedic Medical Journal \{online\} 2020 \{cited November, 2020\} Available from: http://www.iamj.in/posts/images/upload/5111 5114.pdf 